\title{
Prevalence and Associated Factors of Common Mental Disorders in Women: A Systematic Review
}

\author{
Héllyda de Souza Bezerra*, Roberta M. Alves, Aryelly Dayanne d. Nunes and \\ Isabelle R. Barbosa
}

Graduate Program in Public Health, Federal University of Rio Grande do Norte, Natal, Brazil

Objectives: To identify the prevalence and factors associated with common mental disorders in adult women.

Methods: Searches were carried out in the PubMed, Web of Science, Science Direct, Scopus, Cinahl, Google Scholar and Open Gray databases. The study protocol was registered with PROSPERO under number CRD42020168231. Cross-sectional studies showing the prevalence of common mental disorders in women over 18 years were included. Studies with men, children and pregnant women of another age group and with other mental disorders and other types of studies were excluded. The Joanna Briggs Institute checklist was used to assess the risk of bias.

Results: Nineteen studies were included in this review. The prevalence of CMD ranged from $9.6 \%$ to $69.3 \%$. The main associated factors were unemployment, indebtedness, low income, being a housewife, smoking, low education, poor self-rated health, being single, divorced or widowed. The risk of bias in the studies was classified as low and moderate.

Conclusion: This review revealed a variable prevalence rate of CMD in adult women. Public policies are needed to create strategies to prevent the mental illness of these women.

\section{OPEN ACCESS}

Edited by:

Kasia Czabanowska

Maastricht University, Netherlands

*Correspondence:

Héllyda de Souza Bezerra hellydasbezerra@hotmail.com

Received: 05 May 2021 Accepted: 06 August 2021 Published: 23 August 2021

Citation:

Bezerra HdS, Alves RM, Nunes ADd and Barbosa IR (2021) Prevalence and

Associated Factors of Common

Mental Disorders in Women: A

Systematic Review.

Public Health Rev 42:1604234.

doi: 10.3389/phrs.2021.1604234
Keywords: mental health, systematic review, women, prevalence, mental disorders

\section{INTRODUCTION}

Mental disorders are a serious public health problem affecting low, middle and high income countries all over the world, accounting for about one third of mental illness globally. An estimated 322 million people are diagnosed with mental disorders worldwide. In Brazil, 9.3\% of the population have symptoms related to anxiety and $5.8 \%$ have depression $[1,2]$.

Common Mental Disorders (CMD) have anxiety, depression and suicidal ideation as main symptoms of psychological distress, in addition to non-psychotic symptoms such as irritability, insomnia, fatigue and memory problems. However, CMD do not always meet the formal criteria of

\footnotetext{
Abbreviations: CIDI, composite international diagnostic interview; CMD, common mental disorders; DSM-V, diagnostic and statistical manual of mental disorders; GHQ-12, general health questionnaire; GPs, Gatekeeper; K6, Kessler 6; MINI, miniinternational neuropsychiatric interview; PRISMA, preferred reporting items for systematic reviews and meta-analyses; PRIME-MD, primary care evaluation of mental disorders; PROSPERO, international prospective register of systematic reviews; SRQ-20, self-reporting questionnaire.
} 
the international classification of diseases (ICD-10) or the Diagnostic and Statistical Manual of Mental Disorders (DSMV) $[3,4]$.

Common mental disorders affect the activities of daily living, damaging social, family and work environment relationships. In addition, in the case of young adults, they cause socioeconomic vulnerability, decreasing productive capacity and leading to social isolation and increased use of health services [5].

One in five people may to develop CMD during their lifetime, and the probability is higher in the female sex [6]. This can be explained by socio-cultural factors linked to the female sex, which is more exposed to domestic work overload, domestic violence, domestic stressors, and multiple roles developed in society, both in the home and work contexts [7].

In addition to socio-cultural factors, women present biological vulnerability to CMD symptoms particularly linked to the reproductive period. The role of estrogen in mood modulation can explain, in part, the high prevalence of mood and anxiety disorders in women from menarche to menopause. Besides the association between hormonal variation during premenstrual, puerperium and menopause periods and depressive mood, the hormones present in oral contraceptives and hormone replacement therapy also influence mood [8]. The higher prevalence of $\mathrm{CMD}$ in women is also associated with the greater detection of symptoms and search for health services in this sex [9].

The psychological suffering generated by $\mathrm{CMD}$ in adult women triggers a lower quality of life and difficulty in developing activities of daily living. Despite the understanding about the population segments most vulnerable to CMD, research on mental health, specifically of adult women, is still scarce [10]. Identifying the magnitude of this problem and the most vulnerable groups allows proposing public policies aimed at women's health and planning more effective health actions to prevent these disorders, as well as encouraging multidisciplinary interventions to adequately treat women who have CMD.

Besides being essential to know the prevalence of CMD in adult women, it is also necessary to know the factors associated with these disorders, so that they can be prevented and the number of patients with CMD can be minimized. The goal of this study was to identify the prevalence and associated factors of CMD in adult women. The following research question was proposed: "What is the prevalence of CMD in adult women and what are the associated factors?".

\section{METHODS}

\section{Protocol and Registration}

To start this systematic review, a protocol was created and registered in the International Prospective Register of Systematic Reviews (PROSPERO) (CRD42020168231). The Preferred reporting items for systematic reviews and meta-analyses (PRISMA) statement [11] was used as a guide to write this review.

\section{Eligibility Criteria}

Cross-sectional studies reporting data on prevalence of CMD and associated factors in women over 18 years were included. Studies with the following characteristics were excluded: 1) conducted with men, children and pregnant women; 2) conducted with women under 18 ; 3) addressing other mental disorders and/or diseases; 4) not presenting prevalence rates and/or associated factors, or insufficient data for calculations; 5) cohort studies, case-control studies, diagnostic studies, clinical trials, reviews, letter to the editor, conference abstracts, and opinion articles.

\section{Sources of Information}

Searches were conducted in the PubMed, Web of Science, Science Direct, Scopus, Cinahl databases, in addition to the Google Scholar and Open Gray. No restrictions as to language or publication date were adopted. A librarian was consulted during the search strategy in the bibliographic bases. The MeSH terms and key words "Women" and "Mental Disorders," "Women's Groups" and "behavior disorders" and the key word "common mental disorders" were used in the search (Supplementary Appendix SA). Experts were consulted via e-mail to find more references.

The results obtained in the database search were inserted in the reference manager Mendeley Desktop ${ }^{\circledR}$ version 1.19.4 for the elimination of duplicates. Then, the resulting articles were transferred to Rayyan QCRI ${ }^{\circledR}$ software to be sorted by titles and abstracts. Searches were carried out on January 12, 2020.

\section{Study Selection}

Titles and abstracts were read and those that met the eligibility criteria were read in full length. All steps were performed by two independent researchers (HSB and RMA). In both stages, meetings were held to resolve disagreements and reach consensus; there was no need to consult the third reviewer (IRB).

After the initial screening, the results obtained were submitted to complete textual reading in the Rayyan $\mathrm{QCRI}^{\circledR}$ used ensure blindness during the research, based on the eligibility criteria. After this analysis, studies were selected to be included in the systematic review.

\section{Data Extraction}

The data collected from the studies selected by the first and second authors independently (HSB and RMA) were: authors, year of publication, city, country, sample size, age of participants, prevalence of CMD, methods, instruments for identifying CMD, and associated factors in the adjusted analysis. The types of associated factors were not selected beforehand, but were inserted as they were found in the studies. In both stages, disagreements were resolved through consensus meetings; there was no need to consult the third reviewer (IRB).

\section{Risk of Bias}

The methodological quality of the included studies was evaluated by the Checklist for Analytical Cross Sectional Studies from The Joanna Briggs Institute [12].

The eight questions were answered by the first and second reviewers independently with "Yes," "No," "Unclear" or "Not applicable." When necessary, a consensus meeting was held. The risk of bias results was classified into 1) low risk, if the studies reached more than $70 \%$ of "yes" scores; 2 ) moderate risk, if the studies reached between 50 and $69 \%$ of "yes" scores; and 3) high 


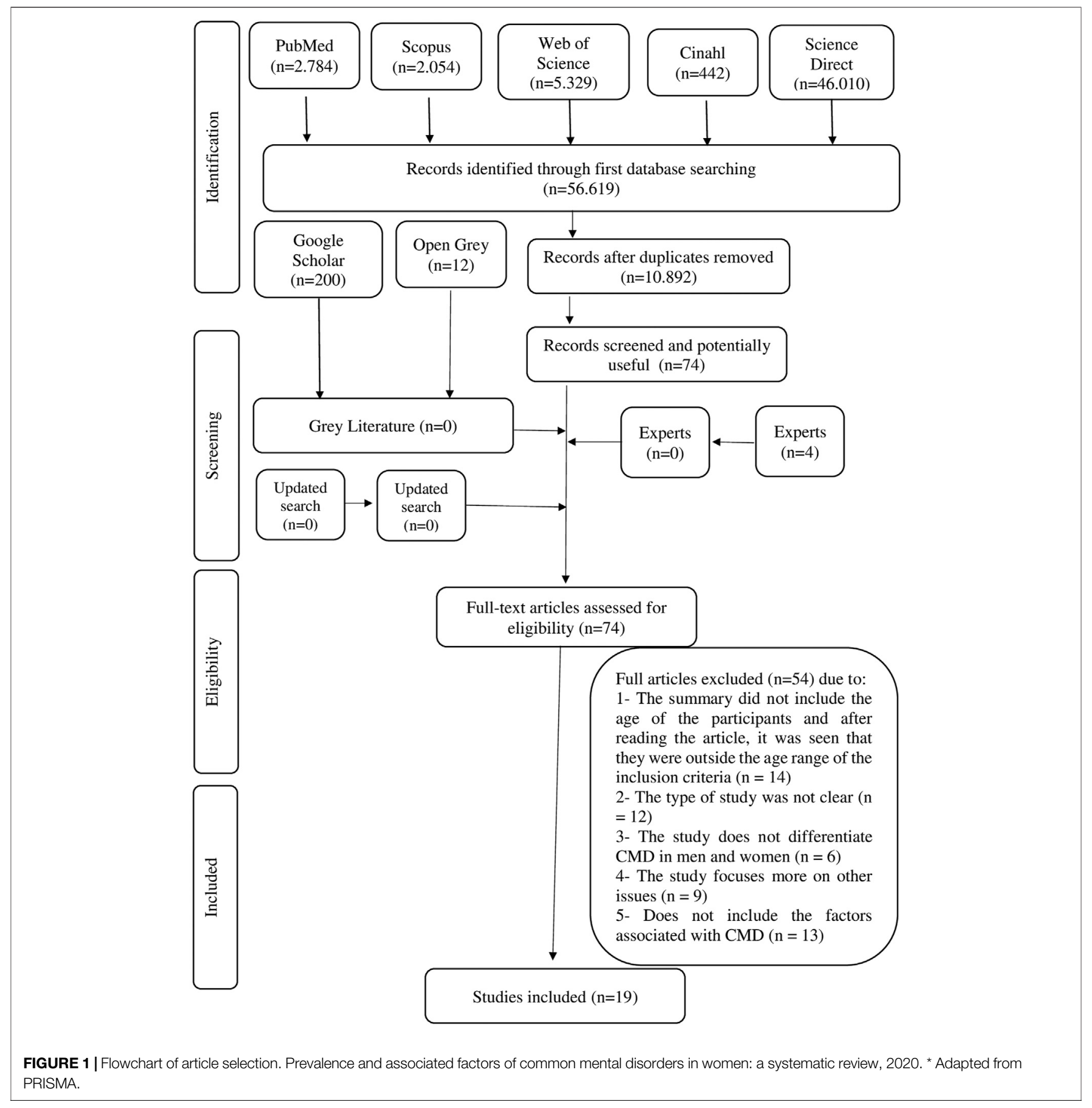

risk, if the studies reached less than 49\% "yes" scores [13]. The graphical illustration of risk of bias was created using the Review Manager 5.3 software (RevMan 5.3, The Nordic Cochrane Center, Copenhagen, Denmark).

\section{RESULTS}

\section{Search Results}

A total of 56,619 articles were found in the searches. After removing the duplicates, 10,892 articles remained for reading of titles and abstracts. In the screening phase, the titles and abstracts were read, and those that did not meet the eligibility criteria were subsequently excluded. The main exclusion criteria were related to the participants' age (exclusion criteria 1 and 2). Therefore, 74 articles were read in full length; and of these, 54 were excluded (Supplementary Appendix SB) following the same criteria. No study from the gray literature was included. There was no reply from the experts contacted. Thus, 19 articles were included in this systematic review (Figure 1). 
TABLE 1 | Characteristics of the included studies. Prevalence and associated factors of common mental disorders in women: a systematic review, 2020.

\begin{tabular}{|c|c|c|c|c|c|c|}
\hline Authors & $\begin{array}{l}\text { City/ } \\
\text { Country }\end{array}$ & $\begin{array}{l}\text { Age in } \\
\text { years } \\
\text { (mean) }\end{array}$ & Sample & $\begin{array}{l}\text { Method for identification } \\
\text { of CMD }\end{array}$ & Prevalence of CMD & Associated factors $(95 \% \mathrm{Cl})$ \\
\hline $\begin{array}{l}\text { Ansseaua } \\
\text { et al. [14] }\end{array}$ & Belgium & Over 18 & 1,360 & $\begin{array}{l}\text { Questionnaire for mental } \\
\text { disorders (PRIME-MD) }\end{array}$ & $\begin{array}{l}\text { MD: } 35.3 \% \\
\text { MDD: } 3.8 \% \\
\text { AD: } 21.9 \%\end{array}$ & 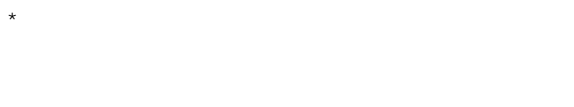 \\
\hline $\begin{array}{l}\text { Duran } \\
\text { et al. [22] }\end{array}$ & United States & $\begin{array}{l}18 \text { to } 45 \\
\text { (mean } \\
27.8 \text { ) }\end{array}$ & 234 & $\begin{array}{l}\text { Questionnaire for mental } \\
\text { disorders (GHQ-12) }\end{array}$ & $\begin{array}{l}\text { MD: } 44 \% \\
\text { AD: } 58 \%\end{array}$ & $\begin{array}{l}\text { Debts: } \mathrm{PR}=1.5(95 \% \mathrm{Cl}=1.1-2.1) \\
\text { Poor self-rated health: } \mathrm{PR}=1.5(95 \% \mathrm{Cl}=1.2-2.0) \\
\text { Debts } \mathrm{PR}=1.4(95 \% \mathrm{Cl}=1.1-1.9) \\
\text { Low educational level (below high school) } \mathrm{PR}=1.4 \\
(95 \% \mathrm{Cl}=1.1-1.7) ; \text { Poor self-rated health: } \mathrm{PR}=1.4 \\
(95 \% \mathrm{Cl}=1.1-1.6)\end{array}$ \\
\hline $\begin{array}{l}\text { Girolamo } \\
\text { et al. [23] }\end{array}$ & Italy & Over 18 & 2,391 & $\begin{array}{l}\text { Questionnaire for mental } \\
\text { disorders (CIDI) }\end{array}$ & $\begin{array}{l}\text { Prevalence of any } \\
\text { mental disorder: } \\
24.4 \% \% \\
\text { Prevalence of } \\
\text { MD: } 14.9 \% \\
\text { Prevalence of } \\
\text { AD: } 16.2 \%\end{array}$ & 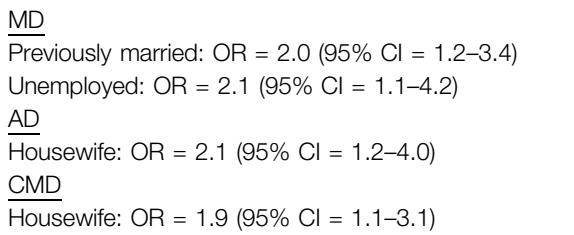 \\
\hline $\begin{array}{l}\text { Cohidon } \\
\text { et al. [24] }\end{array}$ & France & Over 18 & 21,337 & $\begin{array}{l}\text { Mini-International } \\
\text { Neuropsychiatric Interview } \\
\text { (MINI) }\end{array}$ & $\begin{array}{l}\text { MD: } 16 \% \\
\text { AD: } 25 \%\end{array}$ & * \\
\hline $\begin{array}{l}\text { Campo- } \\
\text { Arias } \\
\text { et al. [21] }\end{array}$ & Colombia & $\begin{array}{l}18 \text { to } 65 \\
\text { (mean } \\
38.3 \text { ) }\end{array}$ & 1,740 & $\begin{array}{l}\text { Questionnaire for mental } \\
\text { disorders (GHQ-12) }\end{array}$ & CMD: $15.7 \%$ & $\begin{array}{l}\text { Alcohol abuse: } \mathrm{OR}=6.4(95 \% \mathrm{Cl}=2.7-15.2) \\
\text { Daily smoking: } \mathrm{OR}=3.3(95 \% \mathrm{Cl}=2.1-5.0) \\
\text { Chronic diseases: } \mathrm{OR}=2.0(95 \% \mathrm{Cl}=1.4-2.8) \\
\text { Daily coffee consumption: } \mathrm{OR}=1.3(95 \% \mathrm{Cl}=1.0-1.8)\end{array}$ \\
\hline $\begin{array}{l}\text { Fortes } \\
\text { et al. [19] }\end{array}$ & Brazil & 18 to 65 & 327 & $\begin{array}{l}\text { Questionnaire for mental } \\
\text { disorders (GHQ-12) }\end{array}$ & $\begin{array}{l}\text { CMD in extremely poor } \\
\text { women: } 69.35 \\
\text { CMD in women who are } \\
\text { not extremely poor: } \\
56.78 \%\end{array}$ & $\begin{array}{l}\text { Single marital status: } \mathrm{OR}=1.23(95 \% \mathrm{Cl}=1.08-1.40) \text {, } \\
\text { Poverty level: family income per capita less than US } \$ 40 \\
\text { per month: OR }=1.08(95 \% \mathrm{Cl}=0.95-1.24) \text { and } \\
\text { extremely poor women }\end{array}$ \\
\hline $\begin{array}{l}\text { Ghuloum } \\
\text { et al. [31] }\end{array}$ & Qatar & 18 to 65 & 893 & $\begin{array}{l}\text { Self-administered } \\
\text { questionnaire validated by } \\
\text { the authors }\end{array}$ & $\begin{array}{l}\text { CDM: } 55.6 \% \\
\text { MDD: } 13.3 \\
\text { AD: } 10.9 \% \\
\text { Phobia: } 6.6 \%\end{array}$ & $\begin{array}{l}\frac{\mathrm{CMD}}{\text { Age group, marital status, education, occupation, and }} \\
\text { monthly family income }(p<0.001)\end{array}$ \\
\hline $\begin{array}{l}\text { Jansen } \\
\text { et al. [20] }\end{array}$ & Brazil & 18 to 24 & 880 & $\begin{array}{l}\text { Screening questionnaire for } \\
\text { common mental disorders } \\
\text { (SRQ-20) and Quality of Life } \\
\text { Questionnaire (SF-36) }\end{array}$ & CDM: $32.2 \%$ & 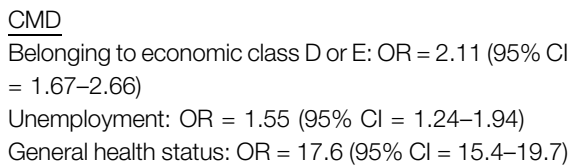 \\
\hline $\begin{array}{l}\text { Menil } \\
\text { et al. [29] }\end{array}$ & Ghana & $\begin{array}{l}\text { Over } \\
18 \text { years } \\
\text { (mean } 37)\end{array}$ & 2,814 & $\begin{array}{l}\text { Questionnaire for mental } \\
\text { disorders (Kessler } 6 \text { - K6) }\end{array}$ & $\begin{array}{l}\text { This study failed to } \\
\text { estimate the prevalence } \\
\text { of CMD because the K6 } \\
\text { tool, commonly used } \\
\text { for this purpose, has not } \\
\text { yet been indexed in } \\
\text { Ghana. The average } \\
\text { score found on K6 } \\
\text { was } 27.1\end{array}$ & $\begin{array}{l}\frac{C M D}{\text { Low levels of education, poverty and unemployment }} \\
(p=0.001,0.02,0.0001 \text {, respectively) }\end{array}$ \\
\hline $\begin{array}{l}\text { Skapinakis } \\
\text { et al. [25] }\end{array}$ & Greece & $\begin{array}{l}18 \text { to } 70 \\
\text { (mean } 42 \pm \\
15 \text { SD) }\end{array}$ & 2,466 & $\begin{array}{l}\text { Questionnaire for mental } \\
\text { disorders (CIS-R) }\end{array}$ & $\begin{array}{l}\text { MDD: } 3.68 \% \\
\text { AD: } 8.45 \% \\
\text { All phobias: } 3.64 \%\end{array}$ & 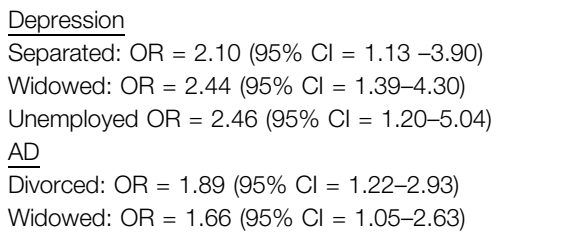 \\
\hline $\begin{array}{l}\text { Jurado } \\
\text { et al. [26] }\end{array}$ & Spain & 18 to 50 & 906 & $\begin{array}{l}\text { Questionnaire for mental } \\
\text { disorders (Kessler 6-K6) }\end{array}$ & $\begin{array}{l}\text { CDM: } 9.6 \% \text { in Spanish } \\
\text { women } \\
\text { CDM: } 24.9 \% \text { in migrant } \\
\text { women }\end{array}$ & $\begin{array}{l}\text { Divorced or widowed: } \mathrm{OR}=2.1(95 \% \mathrm{Cl}=1.3-3.5) \\
\text { Unemployed or housewife: } \mathrm{OR}=0.59(95 \% \mathrm{Cl}= \\
0.35-1.0) \\
\text { Daily smoking: } \mathrm{OR}=1.4(95 \% \mathrm{Cl}=0.97-2.2) \\
\text { Being a migrant: } \mathrm{OR}=3.1(95 \% \mathrm{Cl}=2.1-4.6)\end{array}$ \\
\hline Borges [6] & Brazil & $\begin{array}{l}\text { Over } 18 \\
\text { (mean 45) }\end{array}$ & 365 & $\begin{array}{l}\text { Screening questionnaire for } \\
\text { common mental disorders } \\
\text { (SRQ-20) }\end{array}$ & CDM: $44.1 \%$ & $\begin{array}{l}\text { Lower quality of life in the domains: physical }(p<0.001) \text {, } \\
\text { psychological }(p=0.018) \text {, and social relationships } \\
(p=0.001)\end{array}$ \\
\hline
\end{tabular}

(Continued on following page) 
TABLE 1 | (Continued) Characteristics of the included studies. Prevalence and associated factors of common mental disorders in women: a systematic review, 2020.

\begin{tabular}{|c|c|c|c|c|c|c|}
\hline Authors & $\begin{array}{l}\text { City/ } \\
\text { Country }\end{array}$ & $\begin{array}{l}\text { Age in } \\
\text { years } \\
\text { (mean) }\end{array}$ & Sample & $\begin{array}{l}\text { Method for identification } \\
\text { of CMD }\end{array}$ & Prevalence of CMD & Associated factors $(95 \% \mathrm{Cl})$ \\
\hline $\begin{array}{l}\text { Soni } \\
\text { et al. [28] }\end{array}$ & India & 18 to 45 & 658 & $\begin{array}{l}\text { Screening questionnaire for } \\
\text { common mental disorders } \\
\text { (SRQ-20) }\end{array}$ & CMD: $22.8 \%$ & $\begin{array}{l}\text { Report of a worse health state: } \mathrm{OR}=9.34(95 \% \\
\mathrm{Cl}=5.93-14.70) \text { and Health income expenditure: } \\
\mathrm{OR}=2.25(95 \% \mathrm{Cl}=1.48 \text { to } 3.44) \\
\text { Increase in the number of consultations in the } \\
\text { previous year: } \mathrm{OR}=1.22(95 \% \mathrm{Cl}=1.05-1.42)\end{array}$ \\
\hline $\begin{array}{l}\text { Gjesdal } \\
\text { et al. [27] }\end{array}$ & Norway & 18 to 67 & 45,399 & $\begin{array}{l}\text { Gatekeeper (GPs) model for } \\
\text { healthcare }\end{array}$ & $\begin{array}{l}\text { Depression: } 43 \% \\
\text { Anxiety: } 23 \% \\
\text { Stress: } 75 \% \\
\text { Sleep problems } \\
\text { All: } 47 \%\end{array}$ & $\begin{array}{l}\text { Low education (high school): } \mathrm{OR}=0.90 \\
(95 \% \mathrm{Cl}=0.85-0.95) \\
\text { Divorced: } \mathrm{OR}=1.17(95 \% \mathrm{Cl}=1.10-1.24)\end{array}$ \\
\hline $\begin{array}{l}\text { Husain } \\
\text { et al. [30] }\end{array}$ & Kenya & Over18 & 429 & $\begin{array}{l}\text { Screening questionnaire for } \\
\text { common mental disorders } \\
\text { (SRQ-20) }\end{array}$ & CDM: $20 \%$ & $\begin{array}{l}\text { Financial difficulties: } \mathrm{OR}=4.3(95 \% \mathrm{Cl}=2.5-7.3) \\
\text { Relationship difficulties: } \mathrm{OR}=1.4(95 \% \mathrm{Cl}=0.6-3,4)\end{array}$ \\
\hline $\begin{array}{l}\text { Audi } \\
\text { et al. [15] }\end{array}$ & Brazil & $\begin{array}{l}\text { Over } 18 \\
\text { (mean } \\
30.8 \pm \\
9.6 \mathrm{SD} \text { ) }\end{array}$ & 1,013 & $\begin{array}{l}\text { Screening questionnaire for } \\
\text { common mental disorders } \\
\text { (SRQ-20) }\end{array}$ & CDM: $66.7 \%$ & $\begin{array}{l}\text { Unemployment: } \mathrm{OR}=1.37(95 \% \mathrm{Cl}=1.04-1.80) \\
\text { Smoking: } \mathrm{OR}=1.58(95 \% \mathrm{Cl}=1.18-2.11) \\
\text { Physical inactivity: } \mathrm{OR}=1.56(95 \% \mathrm{Cl}=1.19-2.13) \\
\text { Violence witnessed in the family during childhood or } \\
\text { adolescence: } \mathrm{OR}=1.40(95 \% \mathrm{Cl}=1.05-1.86)\end{array}$ \\
\hline $\begin{array}{l}\text { Santos } \\
\text { et al. [18] }\end{array}$ & Brazil & 20 to 59 & 369 & $\begin{array}{l}\text { Screening questionnaire for } \\
\text { common mental disorders } \\
\text { (SRQ-20) and assessment } \\
\text { of intimate partner violence } \\
\text { (Conflict Tactic Scales } \\
\text {-CTS-2) }\end{array}$ & $\begin{array}{l}\text { Symptoms of } \\
\text { depressed and anxious } \\
\text { mood: } 79.4 \% \\
\text { Somatic } \\
\text { symptoms: } 78.8 \% \\
\text { Symptoms of } \\
\text { depressive } \\
\text { thoughts: } 78.8 \% \\
\text { * The authors calculated } \\
\text { from the results of the } \\
\text { study }\end{array}$ & $\begin{array}{l}\text { Physical abuse without sequelae (minor): OR }=1.82 \\
\text { ( } 95 \% \mathrm{Cl}=1.01-3.30) \\
\text { Physical abuse without sequelae (severe): } \mathrm{OR}=2.58 \\
(95 \% \mathrm{Cl}=1.06-6.25) \\
\text { Physical abuse with sequelae (minor): } \mathrm{OR}=3.7(95 \% \mathrm{Cl} \\
=1.29-10.63)\end{array}$ \\
\hline $\begin{array}{l}\text { Rocha } \\
\text { et al. [16] }\end{array}$ & Brazil & $\begin{array}{l}19 \text { to } 82 \\
\text { (mean } \\
38.96 \text { ) }\end{array}$ & 2099 & $\begin{array}{l}\text { Screening questionnaire for } \\
\text { common mental disorders } \\
\text { (SRQ-20) }\end{array}$ & CDM: $22.7 \%$ & Unemployment: OR = $1.13(95 \% \mathrm{Cl}=1.08-1.18)$ \\
\hline $\begin{array}{l}\text { Rocha } \\
\text { et al. [17] }\end{array}$ & Brazil & $\begin{array}{l}19 \text { to } 82 \\
\text { (mean } \\
38.96 \text { ) }\end{array}$ & 2099 & $\begin{array}{l}\text { Screening questionnaire for } \\
\text { common mental disorders } \\
\text { (SRQ-20) }\end{array}$ & CMD: $22.7 \%$ & Leisure: $\mathrm{OR}=0.50(95 \% \mathrm{Cl}=950.35-0.72)$ \\
\hline
\end{tabular}

Legend: * There are no association values; Cl, confidence interval; OR, odds ratio; CMD, common mental disorders; MD, mood disorders; MDD, minor depressive disorders; $A D$, anxiety disorders.

\section{Characteristics of the Included Studies}

Publication year of the study: the included studies (Table 1) were published from 2004 [14] to 2018 [15-18].

Study site: The articles included several countries, spread over four continents. Of the 19 articles, eight were developed in South American countries: Brazil [6, 15-20] and Colombia [21]; one was developed in North America: United States [22]; six were developed in Europe: Belgium [14], Italy [23], France [24], Greece [25], Spain [26], Norway [27]; two were developed in Asia: Qatar [24], India [28]; and two were developed in Africa: Ghana [29] and Kenya [30].

Sample size: the studies presented different sample sizes, varying from 234 [6] to 45,399 women [27].

Participants' age: seven studies included women over 18 years old, without specifying the age group, five studies included women up to 59 years old, and seven studies included elderly women (over 60 years old). The studies by Rocha et al. [16] and Rocha et al. [17] included women up to 82 years old, with a mean age of 38.96 years. In the studies by Duran et al. [22] and Borges et al. [6], the included participants had an average age of 27.8 and 45, respectively, being the lowest and highest averages found in the studies analyzed. The majority of the studies did not include elderly women.

Prevalence of CMD: nine articles presented the prevalence for each of the disorders, such as mood disorders, minor depressive disorders, anxiety and some phobias $[14,18,20$, $22,23,25,27,31]$ and 10 presented a single prevalence value for all CMD [6, 15-17, 19-21, 26, 28, 30] The prevalence of CMD varied from 9.6\% [26] to $69.3 \%$ [19].

The instruments used to identify CMD: As for the instruments used to identify CMD, there was variation among the instruments used. The most used instrument (seven studies) $[6,15-17,20,28,30]$ was the Self-Reporting Questionnaire (SRQ-20). The others used other instruments to screen for mental disorders: Primary Care Evaluation of Mental Disorders (PRIME-MD) [14], Mini-International Neuropsychiatric Interview (MINI) [24], General Health Questionnaire (GHQ-12) [19, 21], the Composite 
International Diagnostic Interview (CIDI) [23], the Gatekeeper (GPs) for health services [27], and the Kessler 6 (K6) $[26,29]$.

Factors associated with CMD: The studies identified an association between CMD and unemployment [15-17, 20, $23,26]$, having a large number of debts [22, 30], being a housewife $[23,26]$, being a smoker $[15,21,26]$, having a lower educational level $[22,27,31]$, having poor self-rated health [22, 28] being single [19] divorced [25, 27] or widow [27], and having low income $[19,20,31]$. Leisure activities were a protective factor against CMD [16]. Two studies showed no associated measures. Accordingly, associated factors were presented in 17 studies.

\section{Risk of Bias}

Regarding the risk of bias, the studies were classified as having low $[6,14,16,17,19-28,31]$ and moderate $[15,18,29]$ risk (Supplementary Appendix SC). In the majority of the studies, the items "were confounding factors identified" and "were strategies to deal with confounding factors stated" were scored as presenting a high risk of bias (Figure 2).

\section{DISCUSSION}

The objective of this systematic review was to identify the prevalence and associated factors of CMD in adult women. The prevalence of CMD ranged from 9.6 to $69.3 \%$ and was associated with individual factors and the socioeconomic and work context. Twelve studies had a low risk of bias, showing the good methodological quality of the included studies.

There are several questionnaires for screening and diagnosing mental disorders. Obtaining good results with the use of these questionnaires involves several factors, such as their reliability, validity and high sensitivity. The questionnaires must be short, brief and of easy application [32]. Another factor that directly affects the result is the training of the people who will apply these instruments. The use of the instrument and its proper application improves the capacity to detect CMD. Their inappropriate use, on the other hand, can lead to inadequate screening, underestimating or decreasing the prevalence of CMD [33]. Different instruments used in populations with varied culture, economics and linguistic backgrounds can generate variations in the prevalence of CMD [32], as seen in the present systematic review.

As for the samples, there was a variety, but most studies had probabilistic samples, maintaining the assumptions of internal validity. Therefore, despite the variety of samples, all included studies have representative samples to estimate the prevalence of CMD in adult women. As for the age group of the women, the average ages corresponded to young adult women. The study by Souza et al. [34] showed similar results in their research, related to the disadvantages lived by younger women because they often have a double workload as they work and care for domestic tasks. The women who work and carry this family burden generally renounce their own care in order to take care of the family. This ultimately leads to anxiety, frustration, anguish and mental illness.

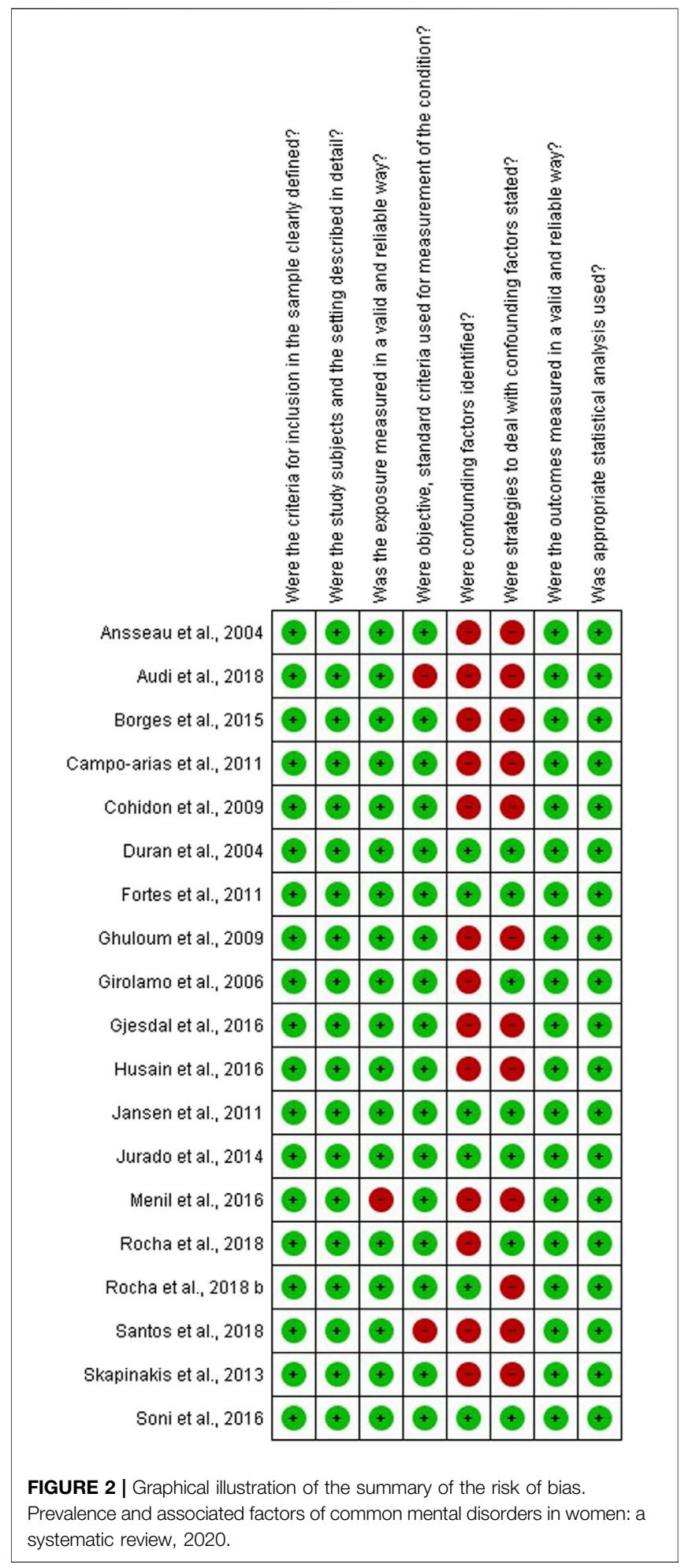

As for the study site, this systematic review included countries from 04 continents (America, Europe, Africa and Asia), demonstrating a good geographic representation and worldwide impact. CMD present a growing increase in numbers worldwide. Africa and America stand out as the 
continents with the highest prevalence of women with depression. America also has the world's highest prevalence of women with anxiety. Regions with lower socioeconomic conditions show worse health conditions and increased rates of CMD [2, 3]. The study by Jurado et al. [26] identified that the lowest prevalence of CMD (9.6\%) occurred in women from Spain. Compared to Spanish women, the chances of CMD were higher for Latin American, Moroccan and other African migrant women. The study on the global burden of mental illness including 28 countries around the world showed that the prevalence of all mental disorders in the past 12 months was higher in Latin American countries than in Spain and other European countries [35]. The low prevalence of CMD found in this systematic review may be explained by the fact that most women with mental disorders in Spain are able to receive primary health care, as well as by the high consumption of psychotropics by women in this country [36].

Latin America was the continent with the largest number of studies in the sample of the present review. In the last few years, mental disorders make up almost a quarter of the existing diseases in this continent, due to the lack of access to treatments and to follow-up [37]. Brazil is the Latin American country with the highest prevalence of people with depression and anxiety in the world, with a high prevalence among women [2]. The study by Fortes et al. [19] conducted in Brazil in the city of Petrópolis/RJ was the one with the highest prevalence of CMD, with a rate of $69.3 \%$ in extremely poor women. This high prevalence rate in Brazil can be explained by multiple factors, such as adverse socioeconomic conditions, high unemployment rates, low education levels, and generalized urban violence [38].

There was considerable variation in the prevalence of mental disorders worldwide and these results should reflect different social and cultural factors of the women included in each study. Steel et al. [3] showed that the global prevalence of CMD was $17.6 \%$, for an adult in the last 12 months, and $29.2 \%$, throughout life. Different causes may be associated, however, with the highest rates of $\mathrm{CMD}$ in continents and countries with precarious conditions of access to health [2]. There are factors that are linked to the particularity of each studied country and/or region, such as cultural, economic and social factors, thus interfering directly in mental health care, being responsible for the increase or reduction of CMD in adult women.

The variation in the prevalence rates of $\mathrm{CMD}$ presented between studies may be related to differences in the characteristics of the populations studied (race and ethnicity, age group, socio-cultural aspects) and to methodological issues, such as the different instruments used for screening and different points of cuts used for the same instrument.

As for the instruments used for screening CMD, the SRQ-20 was the most used. The study by Bolsoni and Zuardi [33] analyzed the reliability and/or internal consistency of brief instruments for tracking multiple mental disorders, and pointed out that the SRQ-20 was widely used in various cultural contexts. This questionnaire is validated in several countries and recommended by the World Health Organization for it meets the criteria in terms of ease of use and reduced cost $[39,40]$. The sensitivity and specificity of this instrument is 83 and $80 \%$, respectively, and the cut-off point for women is $7 / 8$. Regarding the cut-off point, there is a considerable variation in the studies depending on the cultural and temporal context in which the instrument was applied; in some studies, the cut-off point is lower for men (5/6) than for women (7/8), while in others, the cut-off point is $7 / 8$ for both sexes $[8,41]$.

The PRIME-MD was used only in the study by Ansseau et al. [14]. This is an instrument with good diagnostic performance in adults (sensitivity of $83 \%$, specificity of $88 \%$, and positive predictive value of $80 \%$ for the diagnosis of any psychiatric disorder). It assesses groups of CMD found in the general population, namely, mood disorders, anxiety, somatoform disorders, alcohol and eating disorders [42]. The Patient Health Questionnaire-9 (PHQ-9) was created from the PRIME-MD, and it is a more synthesized version, of easier application in adults [43].

With regard to the other questionnaires used for screening CMD, the MINI, the GHQ-12, the CIDI 2.1, and K6 scale are used in the adult population. They are easy and quick to administer, have satisfactory reliability and validity, and present sensitivity and specificity above $80 \%$ [44-47]. The study by Gjesdal et al. [27] used the Norwegian Gatekeeper (GP) model for screening CMD, in which general practitioners formulated the diagnosis at the end of the consultation based on the clinical evaluation.

The diversity of existing instruments to perform CMD screening and the high prevalence of CMD in women make it necessary to validate specific instruments for the female population, considering individual, social and cultural factors. Nevertheless, the included studies considered these factors and conducted a representation of different regions of the world, with low/moderate risk of bias.

As found in the present study as well as in others, multiple factors are associated with CMD in adult women [48-50], including unemployment $[15,16,20,23,26]$, low schooling $[22,27,31]$, and low income [19, 20, 31].

Low education is associated with CMD. According to some studies $[49,51]$, higher schooling generates better cognitive skills, informed decision-making, financial independence, better quality food, leisure and health, directly favoring better physical and mental health status. Low schooling makes women more prone to greater difficulty to find a job, lower salaries, and especially unemployment [52]. Unemployment, which is often caused by fewer years of study, generates financial difficulties and mental suffering [10]. Therefore, smaller number of years of schooling, unemployment and lack of income may be related to the development of CMD in women.

The variable "being a housewife" was a factor associated with CMD in some studies [23, 26]. Many women who are in the role of "housewife" feel devalued, have less autonomy and feel socioeconomically invisible. Furthermore, there is a lack of recognition of the family and society, as they are not within the current productive work standards. All these aspects together generate feelings typical of CMD [53].

Smoking was also a factor associated with $\operatorname{CMD}[15,21,26]$. Although the use of cigarettes is more frequent among men, there is an association between use of cigarette and depression in women (He et al. 2014). Some studies [54-56] also found that 
lower income, low education and not having a partner are related to smoking. It is suggested that lower socioeconomic level can induce stress and this, in turn, is a trigger for the habit of smoking.

Being single [19], divorced [25, 27] and widowed [25] were factors associated with CMD in women. According to Senicato et al. [49], the presence of a partner and a good marital relationship generates social support, minimizing stress situations in the daily life. In marriage, individuals share a wide variety of activities, which include meals, housework, childcare, leisure and rest. The absence of a partner can lead to loneliness and psychological distress.

As for health assessment, two studies [22, 28] showed that women with CMD had a poor self-rated health. In general, women have other comorbidities associated with CMD, which can lead to loss of quality of life [49].

Violence against women $[15,18]$ was another factor associated with CMD. The study by Mendonça and Ludemir [57] showed that psychological, physical and sexual violence by an intimate partner was associated with CMD and the more severe the aggression, the greater the impact on the women's mental health. The growth in domestic violence must be combated in order to minimize the symptoms of CMD and other mental disorders.

Rocha [17] showed that having leisure activities is a protective factor for CMD. As Araújo et al. [58] explain, leisure activities are important for people's well-being and quality of life, reducing symptoms of sadness, depression and anxiety. Regular physical exercise also reduces symptoms of depression, insomnia and improves attention span [59]. Thus, it is observed that the implementation of leisure time and physical exercises in the routine can potentially decrease the prevalence of CMD in women and consequently contribute to their mental and physical well-being.

Common mental disorders in adult women have relevant prevalence rates and associated factors. Reducing the prevalence of $\mathrm{CMD}$ is a challenge for public health, because these cases increase the demand and costs of mental health services and other specialties. Common mental disorders not only generate mental suffering, but can also contribute to the worsening of other associated morbidities such as diabetes, heart problems, cancer, and other diseases. Work absenteeism and consequent economic implications are another problem generated by CMD [60].

It is necessary that public policies and programs focused on women's mental health be able to implement strategies for screening $\mathrm{CMD}$ and other disorders. It is important to understand the role of the female sex in CMD, from the in a biological and social point of view, so as to create different strategies for the sexes. Some contexts of health services that serve women should be changed, including professionals trained to develop actions for the prevention and treatment of mental disorders in women, so that management and the community recognize that $\mathrm{CMD}$ constitute a public health problem and that women should be evaluated for their mental health in routine primary health care, with actions to minimize the impact of these disorders on women's health [6].

As for the limitations of the included studies, as they were crosssectional studies, it is not possible to determine cause-and-effect relations between variables, that is, it is not possible to say whether CMD influence the associated factors or vice versa. Another aspect is that the information in the studies is self-reported and this may generate information bias. Most instruments assess current symptoms, but do not allow the assessment of follow-up of the symptoms. Another limitation found was the lack of identification of confounding factors and of strategies to deal with them in the majority of the studies, indicated in the assessment of the risk of bias.

About the limitation of the present review, articles using different methodologies and samples, different instruments for specific populations, and different cut-off points were included, and this may have caused the wide variability in prevalence rates. Due to this heterogeneity, it was not possible to perform a metaanalysis. Despite the limitations, the present review was carried out with a rigorous methodology by independent authors and reunites important results to guide health policies.

\section{Conclusion}

This review revealed a variation in the prevalence rate of CMD in adult women, with a minimum of $9.6 \%$ and maximum of $69.3 \%$. The studies included in this review showed multiple factors associated with CMD, however, only a few stood out, namely, unemployment, low income, low education level, smoking, marital status, experiences of violence, and poor self-rated health. These findings were explained by the different social, economic, demographic conditions and access to health services in the countries.

The results obtained in this review provide essential information for health management and can serve as a basis for reflections on public policies aimed at mental health and women's health. Based on the knowledge about the factors associated with CMD, policies are needed to create strategies and social support networks to prevent and minimize these illnesses in women. Other types of studies are essential to establish causal relationships of CMD.

\section{AUTHOR CONTRIBUTIONS}

All authors listed have made a substantial, direct, and intellectual contribution to the work and approved it for publication.

\section{FUNDING}

This study was funded by the National Council for Scientific and Technological Development (CNPQ), grant number 133801/ 2020-9, for the incentive by granting MsC scholarships.

\section{CONFLICT OF INTEREST}

The authors declare that the research was conducted in the absence of any commercial or financial relationships that could be construed as a potential conflict of interest. 


\section{ACKNOWLEDGMENTS}

We are grateful to the Nacional Council for scientific and technological development for supporting the scholarship funding of master student, one of the authors of this is article.

\section{REFERENCES}

1. Baxter, AJ, Patton, G, Scott, KM, Degenhardt, L, and Whiteford, HA. Global Epidemiology of Mental Disorders: what Are We Missing? PLoS One (2013). 8:e65514. doi:10.1371/journal.pone.0065514

2. World Health Organization. Depression and Other Common Mental Disorders: Global Health Estimates. Geneva: WHO (2017).

3. Steel, Z, Marnane, C, Iranpour, C, Chey, T, Jackson, JW, Patel, V, et al. The Global Prevalence of Common Mental Disorders: a Systematic Review and Meta-Analysis 1980-2013. Int J Epidemiol (2014). 43:476-93. doi:10.1093/ije/ dyu038

4. Coutinho, LMS, Matijasevich, A, Scazufca, M, and Menezes, PR. Prevalência de transtornos mentais comuns e contexto social: análise multinível Do São Paulo Ageing \& Health Study (SPAH). Cad Saúde Pública (2014). 30: 1875-83. doi:10.1590/0102-311X00175313

5. Quadros, LCM, Quevedo, LA, Gonçalves, HD, Horta, BL, Motta, JVS, and Gigante, DP. Common Mental Disorders and Contemporary Factors: 1982 Birth Cohort. Rev Bras Enferm (2020). 73:e20180162. doi:10.1590/00347167-2018-0162

6. Borges, TL, Hegadoren, KM, and Miasso, AI. Transtornos mentais comuns e uso de psicofármacos em mulheres atendidas em unidades básicas de saúde em um centro urbano brasileiro. Rev Panam Salud Publica (2015). 38: 195-201.

7. Ferreira Leite, J, Dimenstein, M, Macedo, JPS, Dantas, CB, Silva, EL, and Sousa, AP. Condições De Vida, Saúde Mental E Gênero Em Contextos Rurais: Um Estudo a Partir De Assentamentos De Reforma Agrária Do Nordeste Brasileiro. Av Psicol Latinoam (2017). 35:301-16. doi:10.12804/ revistas.urosario.edu.co/apl/a.4768

8. Andrade, LHSG, Viana, MC, and Silveira, CM. Epidemiologia Dos Transtornos Psiquiátricos Na Mulher. Rev Psiquiatr Clín (2006). 33:43-54. doi:10.1590/S0101-60832006000200003

9. Lucchese, R, Sousa, K, Bonfin, SP, Vera, I, and Santana, FR. Prevalência de transtorno mental comum na atenção primária. Acta Paul Enferm (2014). 27: 200-7. doi:10.1590/1982-0194201400035

10. Santos, GBV, Alves, MCGP, Goldbaum, M, Cesar, CLG, and Gianini, RJ. Prevalência de transtornos mentais comuns e fatores associados em moradores da área urbana de São Paulo, Brasil. Cad Saúde Pública (2019). 35:e00236318. doi:10.1590/0102-311x00236318

11. Liberati, A, Altman, DG, Tetzlaff, J, Mulrow, C, Gotzsche, PC, Ioannidis, JPA, et al. The PRISMA Statement for Reporting Systematic Reviews and MetaAnalyses of Studies that Evaluate Healthcare Interventions: Explanation and Elaboration. Bmj (2009). 339:b2700. doi:10.1136/bmj.b2700

12. The Joanna Briggs Institute. Protocols and Work in Progress. [internet]. Adelaide: JBI (2008).

13. Polmann, H, Domingos, FL, Melo, G, Stuginski-Barbosa, J, Guerra, ENS, Porporatti, AL, et al. Association between Sleep Bruxism and Anxiety Symptoms in Adults: A Systematic Review. J Oral Rehabil (2019). 46: 482-91. doi:10.1111/joor.12785

14. Ansseau, M, Dierick, M, Buntinkx, F, Cnockaert, P, De Smedt, J, Van Den Haute, M, et al. High Prevalence of Mental Disorders in Primary Care. J Affective Disord (2004). 78:49-55. doi:10.1016/S0165-0327(02) 00219-7

15. Audi, CAF, Santiago, SM, Andrade, Mda GG, and Francisco, PMSB. Common Mental Disorder Among Incarcerated Women: A Study on Prevalence and Associated Factors. Ciênc saúde coletiva (2018). 23: 3587-96. doi:10.1590/1413812320182311.30372016

16. Rocha, SV, Barbosa, AR, and Araújo, TM. Common Mental Disorders of Health Care Workers in Bahia State. Acta scientiarum-health Sci (2018). 40: e38398. doi:10.4025/actascihealthsci.v40i0.38398

\section{SUPPLEMENTARY MATERIAL}

The Supplementary Material for this article can be found online at: https://www.ssph-journal.org/articles/10.3389/phrs.2021.1604234/ full\#supplementary-material

17. Rocha, SV, Barbosa, AR, and de Araújo, TM. Simultaneity of Leisure Behaviors and Common Mental Disorders Among Healthcare Workers. Arch Environ Occup Health (2018). 73:360-6. doi:10.1080/ 19338244.2017.1393382

18. Santos, AG, and Monteiro, CFS. Domínios dos transtornos mentais comuns em mulheres que relatam violência por parceiro íntimo. Revista LatinoAmericana de Enfermagem (2018). 26:e3099. doi:10.1590/15188345.0000.3081

19. Fortes, S, Lopes, CS, Villano, LAB, Campos, MR, Gonçalves, DA, and Mari, JJ. Common Mental Disorders in Petrópolis-RJ: a challenge to Integrate Mental Health into Primary Care Strategies. Rev Bras Psiquiatr (2011). 33:150-6. doi:10.1590/S1516-44462011000200010

20. Jansen, K, Mondin, TC, Ores, LC, Souza, LDM, Konradt, CE, Pinheiro, RT, et al. Transtornos mentais comuns e qualidade de vida em jovens: uma amostra populacional de Pelotas, Rio Grande Do Sul, Brasil. Cad Saúde Pública (2011). 27:440-8. doi:10.1590/S0102-311X2011000300005

21. Campo-Arias, A, Herazo, E, Barros-Bermúdez, JA, Rueda-Jaimes, GE, and Díaz-Martínez, LA. Common Mental Disorders in Colombian Women*. Revista Colombiana de Psiquiatría (2011). 40:244-50. doi:10.1016/s00347450(14)60121-9

22. Duran, B, Sanders, M, Skipper, B, Waitzkin, H, Malcoe, LH, Paine, S, et al. Prevalence and Correlates of Mental Disorders Among Native American Women in Primary Care. Am J Public Health (2004). 94:71-7. doi:10.2105/ AJPH.94.1.71

23. de Girolamo, G, Polidori, G, Morosini, P, Scarpino, V, Reda, V, Serra, G, et al. Prevalence of Common Mental Disorders in Italy. Soc Psychiat Epidemiol (2006). 41:853-61. doi:10.1007/s00127-006-0097-4

24. Cohidon, C, Imbernon, E, and Gorldberg, M. Prevalence of Common Mental Disorders and Their Work Consequences in France, According to Occupational Category. Am J Ind Med (2009). 52:141-52. doi:10.1002/ ajim. 20656

25. Skapinakis, P, Bellos, S, Koupidis, S, Grammatikopoulos, I, Theodorakis, PN, and Mavreas, V. Prevalence and Sociodemographic Associations of Common Mental Disorders in a Nationally Representative Sample of the General Population of Greece. BMC Psychiatry (2013). 13:163. doi:10.1186/1471244X-13-163

26. Jurado, D, Mendieta-Marichal, Y, Martínez-Ortega, JM, Agrela, M, Ariza, C, Gutiérrez-Rojas, L, et al. World Region of Origin and Common Mental Disorders Among Migrant Women in Spain. J Immigrant Minor Health (2014). 16:1111-20. doi:10.1007/s10903-013-9927-0

27. Gjesdal, S, Holmaas, TH, Monstad, K, and Hetlevik, Ø. GP Consultations for Common Mental Disorders and Subsequent Sickness Certification: RegisterBased Study of the Employed Population in Norway. Famprj (2016). 33: 656-62. doi:10.1093/fampra/cmw072

28. Soni, A, Fahey, N, Byatt, N, Prabhakaran, A, Moore Simas, TA, Vankar, J, et al. Association of Common Mental Disorder Symptoms with Health and Healthcare Factors Among Women in Rural Western India: Results of a Cross-Sectional Survey. BMJ Open (2016). 6:e010834. doi:10.1136/bmjopen2015-010834

29. de Menil, V, Osei, A, Douptcheva, N, Hill, AG, Yaro, P, and De-Graft Aikins, A. Symptoms of Common Mental Disorders and Their Correlates Among Women in Accra, Ghana: a Population-Based Survey. Ghana Med J (2012). 46:95-103.

30. Husain, N, Mukherjee, I, Notiar, A, Alavi, Z, Tomenson, B, Hawa, F, et al. Prevalence of Common Mental Disorders and its Association with Life Events and Social Support in Mothers Attending a Well-Child Clinic. SAGE Open (2016). 6:215824401667732. doi:10.1177/2158244016677324

31. Ghuloum, S, Bener, A, and Abou-Saleh, MT. Prevalence of Mental Disorders in Adult Population Attending Primary Health Care Setting in Qatari Population. J Pak Med Assoc (2011). 61:216-21. 
32. Kagee, A, Tsai, AC, Lund, C, and Tomlinson, M. Screening for Common Mental Disorders in Low Resource Settings: Reasons for Caution and a Way Forward. Int Health (2013). 5:11-4. doi:10.1093/inthealth/ihs004

33. Bolsoni, LM, and Zuardi, AW. Estudos psicométricos de instrumentos breves de rastreio para múltiplos transtornos mentais. J Bras Psiquiatr (2015). 64: 63-9. doi:10.1590/0047-2085000000058

34. Souza, LPS, Barbosa, BB, Silva, CSO, Souza, AG, Ferreira, TN, and Siqueira, LG. Prevalência de transtornos mentais comuns em adultos no contexto da Atenção Primária à Saúde. Rpesm (2017). 18:59-66. doi:10.19131/rpesm.0193

35. Kessler, RC, Aguilar-Gaxiola, S, Alonso, J, Chatterji, S, Lee, S, Ormel, J, et al. The Global burden of Mental Disorders: an Update from the WHO World Mental Health (WMH) Surveys. Epidemiol Psichiatr Soc (2009). 18:23-33. doi:10.1017/S1121189X00001421

36. Henares Montiel, J, Ruiz-Pérez, I, and Sordo, L. Salud mental en España y diferencias por sexo y por comunidades autónomas. Gaceta Sanitaria (2020). 34:114-9. doi:10.1016/j.gaceta.2019.03.002

37. Troya, MI, Bartlam, B, and Chew-Graham, C. Involving the Public in Health Research in Latin America: Making the Case for Mental Health. Rev Panam Salud Publica (2018). 42:1-6. doi:10.26633/RPSP.2018.45

38. Gonçalves, DA, Mari, JJ, Bower, P, Gask, L, Dowrick, C, Tófoli, LF, et al. Brazilian Multicentre Study of Common Mental Disorders in Primary Care: Rates and Related Social and Demographic Factors. Cad Saúde Pública (2014). 30:623-32. doi:10.1590/0102-311X00158412

39. World Health Organization. A User's Guide to the Self Reporting Questionnaire. Geneva: WHO (1993).

40. Gonçalves, DM, Stein, AT, and Kapczinski, F. Avaliação de desempenho Do Self-Reporting Questionnaire como instrumento de rastreamento psiquiátrico: um estudo comparativo com o Structured Clinical Interview for DSM-IV-TR. Cad Saúde Pública (2008). 24:380-90. doi:10.1590/s0102$311 \times 2008000200017$

41. Santos, KOB, Araújo, TM, Pinho, PAS, and Silva, ACC. Avaliação de um instrumento de mensuração de morbidade psíquica: estudo de validação Do Self-Reporting Questionnaire (SQQR-20). Rev Baiana Saúde Pública (2010). 34:544-60.

42. Spitzer, RL, Kroenke, K, Linzer, M, Hahn, SR, Williams, JBW, deGruy, FV, et al. Health-Related Quality of Life in Primary Care Patients with Mental Disorders. JAMA (1995). 274:1511-7. doi:10.1001/ jama.1995.03530190025030

43. Santos, IS, Tavares, BF, Munhoz, TN, Almeida, LSP, Silva, NTB, Tams, BD, et al. Sensibilidade e especificidade Do Patient Health Questionnaire-9 (PHQ-9) entre adultos da população geral. Cad Saúde Pública (2013). 29: 1533-43. doi:10.1590/s0102-311x2013001200006

44. Amorim, P. Mini International Neuropsychiatric Interview (MINI): validação de entrevista breve para diagnóstico de transtornos mentais. Rev Bras Psiquiatr (2000). 22:106-15. doi:10.1590/S1516-44462000000300003

45. Kessler, RC, Green, JG, Gruber, MJ, Sampson, NA, Bromet, E, Cuitan, M, et al. Screening for Serious Mental Illness in the General Population with the K6 Screening Scale: Results from the WHO World Mental Health (WMH) Survey Initiative. Int J Methods Psychiatr Res (2010). 19(Suppl. 1):4-22. doi:10.1002/mpr.310

46. Endsley, P, Weobong, B, and Nadkarni, A. The Psychometric Properties of GHQ for Detecting Common Mental Disorder Among Community Dwelling Men in Goa, India. Asian J Psychiatry (2017). 28:106-10. doi:10.1016/ j.ajp.2017.03.023

47. Quintana, MI, Mari, JJ, Ribeiro, WS, Jorge, MR, and Andreoli, SB. Accuracy of the Composite International Diagnostic Interview (CIDI 2.1) for Diagnosis of post-traumatic Stress Disorder According to DSM-IV Criteria. Cad Saúde Pública (2012). 28:1312-8. doi:10.1590/S0102-311X2012000700009

48. Parreira, BDM, Goulart, BF, Haas, VJ, Silva, SR, Monteiro, JCS, and GomesSponholz, FA. Common Mental Disorders and Associated Factors: a Study of Women from a Rural Area. Rev Esc Enferm USP (2017). 51:e03225. doi:10.1590/S1980-220X2016033103225

49. Senicato, C, Azevedo, RCS, and Barros, MBA. Transtorno Mental Comum Em Mulheres Adultas: Identificando Os Segmentos Mais Vulneráveis. Ciênc Saúde Coletiva (2018). 23:2543-54. doi:10.1590/141381232018238.13652016

50. Nunes, MA, Pinheiro, AP, Bessel, M, Brunoni, AR, Kemp, AH, Benseñor, IM, et al. Common Mental Disorders and Sociodemographic Characteristics:
Baseline Findings of the Brazilian Longitudinal Study of Adult Health (ELSABrasil). Rev Bras Psiquiatr (2016). 38:91-7. doi:10.1590/1516-4446-20151714

51. Bates, LM, Berkman, LF, and Maria Glymour, M. Socioeconomic Determinants of Women's Health. Women Health (2013). 22:671-83. doi:10.1016/b978-0-12-384978-6.00044-3

52. Patel, V, and Kleinman, A. Poverty and Common Mental Disorders in Developing Countries. Bull World Health Organ (2003). 81:609-15.

53. Santos, LD, and Diniz, GRS. Saúde mental das mulheres donas de casa: um olhar feminista-fenomenologico-existencial. Psic Clin (2018). 30:37-59. doi:10.33208/PC1980-5438v0030n01A02

54. Lindström, M. Social Capital, Economic Conditions, Marital Status and Daily Smoking: a Population-Based Study. Public Health (2010). 124:71-7. doi:10.1016/j.puhe.2010.01.003

55. Stansfeld, SA, Fuhrer, R, and Head, J. Impact of Common Mental Disorders on Sickness Absence in an Occupational Cohort Study. Occup Environ Med (2011). 68:408-13. doi:10.1136/oem.2010.056994

56. Laaksonen, M, Rahkonen, O, Karvonen, S, and Lahelma, E. Socioeconomic Status and Smoking. Eur J Public Health (2005). 15:262-9. doi:10.1093/ eurpub/cki115

57. Mendonça, MFS, and Ludermir, AB. Violência por parceiro íntimo e incidência de transtorno mental comum. Rev Saude Publica (2017). 51:32. doi:10.1590/s1518-8787.2017051006912

58. Araújo, TM, Carmo Junior, JJ, Almeida, MMG, and Pinho, OS. Práticas de atividades de lazer e morbidade psíquica em residentes de áreas urbanas. Rev Baiana de Saúde Pública (2007). 31:294-310. doi:10.22278/23182660.2007.v31.n0

59. Al-Eisa, E, Buragadda, S, and Melam, GR. Association between Physical Activity and Psychological Status Among Saudi Female Students. BMC Psychiatry (2014). 14:238. doi:10.1186/s12888-014-0238-3

60. Soegaard, HJ. Undetected Common Mental Disorders in Long-Term Sickness Absence. Int J Fam Med (2012). 2012:1-9. doi:10.1155/2012/474989

61. Stewart, RC, Bunn, J, Vokhiwa, M, Umar, E, Kauye, F, Fitzgerald, M, et al. Common Mental Disorder and Associated Factors Amongst Women with Young Infants in Rural Malawi. Soc Psychiat Epidemiol (2010). 45:551-9. doi:10.1007/s00127-009-0094-5

62. Kagee, A, Saal, W, De Villiers, L, Sefatsa, M, and Bantjes, J. The Prevalence of Common Mental Disorders Among South Africans Seeking HIV Testing. AIDS Behav (2017). 21:1511-7. doi:10.1007/s10461-016-1428-4

63. Smolen, JR, De Araújo, EM, De Oliveira, NF, and De Araújo, TM. Intersectionality of Race, Gender, and Common Mental Disorders in Northeastern Brazil. Ethn Dis (2018). 28:207-14. doi:10.18865/ed.28.3.207

64. Chong, SA, Abdin, E, Sherbourne, C, Vaingankar, J, Heng, D, Yap, M, et al. Treatment gap in Common Mental Disorders: the Singapore Perspective. Epidemiol Psychiatr Sci (2012). 21:195-202. doi:10.1017/S2045796011000771

65. Kagee, A, Saal, W, and Bantjes, J. The Relationship between Symptoms of Common Mental Disorders and Drug and Alcohol Misuse Among Persons Seeking an HIV Test. AIDS Care (2018). 30:219-23. doi:10.1080/ 09540121.2017.1361510

66. Shaw, CM, Creed, F, Tomenson, B, Riste, L, Cruickshank, JK, and Rait, G. Prevalence of Anxiety and Depressive Illness and Help Seeking Behaviour in African Caribbeans and white Europeans: Two Phase General Population Survey Commentary: Counting Heads May Mask Cultural and Social Factors. Bmj (1999). 318:302-6. doi:10.1136/bmj.318.7179.302

67. Hanlon, C, Medhin, G, Alem, A, Araya, M, Abdulahi, A, Tesfaye, M, et al. Measuring Common Mental Disorders in Women in Ethiopia. Soc Psychiat Epidemiol (2008). 43:653-9. doi:10.1007/s00127-008-0342-0

68. Van de Velde, S, Boyd, A, Villagut, G, Alonso, J, Bruffaerts, R, De Graaf, R, et al. Gender Differences in Common Mental Disorders: a Comparison of Social Risk Factors across Four European Welfare Regimes. Eur J Public Health (2019). 29:481-7. doi:10.1093/eurpub/cky240

69. Jenkins, R, Othieno, C, Ongeri, L, Sifuna, P, Ongecha, M, Kingora, J, et al. Common Mental Disorder in Nyanza Province, Kenya in 2013 and its Associated Risk Factors-Aan Assessment of Change since 2004, Using a Repeat Household Survey in a Demographic Surveillance Site. BMC psychiatry (2015). 15:309. doi:10.1186/s12888-015-0693-5

70. Neto, JV, Fisberg, RM, Martini, LA, and Ribeiro, SM. Association between Common Mental Disorders and Joint Diseases in Middle and Old Aged 
Women. Data from Health Survey of São Paulo, SP, Brazil. Maturitas (2019). 124:173. doi:10.1016/j.maturitas.2019.04.166

71. Jacka, FN, Maes, M, Pasco, JA, Williams, LJ, and Berk, M. Nutrient Intakes and the Common Mental Disorders in Women. J Affective Disord (2012). 141: 79-85. doi:10.1016/j.jad.2012.02.018

72. Fahey, N, Soni, A, Allison, J, Prabhakaran, JA, Anusha, TM, Byatt, N, et al. Higher Levels of Education Mitigate the Relationship between Perceived Stress and Common Mental Disorders Among Women in Rural India: Results of a Cross-Sectional Study. Ann Glob Health (2016). 82:560. doi:10.1016/j.aogh.2016.04.505

73. Barreto do Carmo, MB, Santos, LM, Feitosa, CA, Fiaccone, RL, Silva, NB, Santos, DN, et al. Screening for Common Mental Disorders Using the SRQ20 in Brazil: what Are the Alternative Strategies for Analysis? Rev Bras Psiquiatr (2018). 40:115-22. doi:10.1590/1516-4446-2016-2139

74. Grammatikopoulos, I, Skapinakis, P, Koupidis, S, Bellos, S, Theodorakis, P, Mavreas, V, et al. EPA-1708 - Common Mental Disorders and Use of Mental Health Services in the General Population in Greece. Eur Psychiatry (2014). 29:1. doi:10.1016/S0924-9338(14)78849-2

75. Rees, S, Steel, Z, Creamer, M, Teesson, M, Bryant, R, McFarlane, AC, et al. Onset of Common Mental Disorders and Suicidal Behavior Following Women $_{\dot{c}}$ s First Exposure to Gender Based Violence: a Retrospective, Population-Based Study. BMC Psychiatry (2014). 14:312. doi:10.1186/ preaccept-2017783131130080

76. Yu, Y, Hu, M, Liu, Z-w, Liu, H-m, Yang, JP, Zhou, L, et al. Recognition of Depression, Anxiety, and Alcohol Abuse in a Chinese Rural Sample: a CrossSectional Study. BMC Psychiatry (2016). 16:93. doi:10.1186/s12888-0160802-0

77. Bhui, K, Warfa, N, and Jones, E. Is Violent Radicalisation Associated with Poverty, Migration, Poor Self-Reported Health and Common Mental Disorders? PLoS One (2014). 9:e90718. doi:10.1371/journal.pone.0090718

78. Ahmad, F, Shakya, Y, Ginsburg, L, Lou, W, Ng, PT, Rashid, M, et al. Burden of Common Mental Disorders in a Community Health centre Sample. Can Fam Physician (2016). 62:e758-e766.

79. Lima, MCP, Domingues, MS, and Cerqueira, ATAR. Prevalência e fatores de risco para transtornos mentais comuns entre estudantes de medicina. Rev Saúde Pública (2006). 40:1035-41. doi:10.1590/S0034-89102006000700011

80. Braden, JB, Zhang, L, Zimmerman, FJ, and Sullivan, MD. Employment Outcomes of Persons with a Mental Disorder and Comorbid Chronic Pain. Ps (2008). 59:878-85. doi:10.1176/ps.2008.59.8.878

81. Brewis, A, Choudhary, N, and Wutich, A. Household Water Insecurity May Influence Common Mental Disorders Directly and Indirectly through Multiple Pathways: Evidence from Haiti. Soc Sci Med (2019). 238:112520. doi:10.1016/j.socscimed.2019.112520

82. Bell, SA, Lori, J, Redman, R, and Seng, J. Development of a Brief Screening Tool for Women's Mental Health Assessment in Refugee Settings: A Psychometric Evaluation. Int J Nurs Stud (2015). 52:1202-8. doi:10.1016/ j.ijnurstu.2015.04.003

83. Cunha, MCV, Carvalho, JA, Albuquerque, RM, Ludermir, AB, and Novaes, M. Infertilidade: associação com transtornos mentais comuns e a importância Do apoio social. Rev Psiquiatr Rio Gd Sul (2008). 30:201-10. doi:10.1590/ S0101-81082008000400009

84. Kallakuri, S, Devarapalli, S, Tripathi, AP, Patel, A, and Maulik, PK. Common Mental Disorders and Risk Factors in Rural India: Baseline Data from the SMART Mental Health Project. BJPsych Open (2018). 4:192-8. doi:10.1192/ bjo. 2018.28

85. Bhui, K, Bhugra, D, Goldberg, D, Dunn, G, and Desai, M. Cultural Influences on the Prevalence of Common Mental Disorder, General Practitioners' Assessments and Help-Seeking Among Punjabi and English People Visiting Their General Practitioner. Psychol Med (2001). 31:815-25. doi:10.1017/S0033291701003853

86. Kermode, M, Bowen, K, Arole, S, Joag, K, and Jorm, AF. Community Beliefs about Causes and Risks for Mental Disorders: a Mental Health Literacy Survey in a Rural Area of Maharashtra, India. Int J Soc Psychiatry (2010). 56: 606-22. doi:10.1177/0020764009345058

87. Lang, IA, Llewellyn, DJ, Hubbard, RE, Langa, KM, and Melzer, D. Income and the Midlife Peak in Common Mental Disorder Prevalence. Psychol Med (2011). 41:1365-72. doi:10.1017/S0033291710002060
88. Kiejna, A, Piotrowski, P, Adamowski, T, Moskalewicz, J, Wciórka, J, Stokwiszewski, J, et al. The Prevalence of Common Mental Disorders in the Population of Adult Poles by Sex and Age Structure - an EZOP Poland Study. Psychiatr Pol (2015). 49:15-27. doi:10.12740/PP/30811

89. Krueger, RF, McGue, M, and Iacono, WG. The Higher-Order Structure of Common DSM Mental Disorders: Internalization, Externalization, and Their Connections to Personality. Personal Individual Differences (2001). 30: 1245-59. doi:10.1016/S0191-8869(00)00106-9

90. Conway, PM, Campanini, P, Punzi, S, Fichera, GP, Camerino, D, Francioli, L, et al. Work Stress, Common Mental Disorders and Work Ability Index Among Call center Workers of an Italian Company. Epidemiol Prev (2013). 37:17-28.

91. Patel, V, Kirkwood, BR, Pednekar, S, Pereira, B, Barros, P, Fernandes, J, et al. Gender Disadvantage and Reproductive Health Risk Factors for Common Mental Disorders in Women. Arch Gen Psychiatry (2006). 63:404-13. doi:10.1001/archpsyc.63.4.404

92. Puertas, G, Ríos, C, and Valle, H. Prevalencia de trastornos mentales comunes en barrios marginales urbanos con población desplazada en Colombia. Rev Panam Salud Publica (2006). 20:324-30. doi:10.1590/s102049892006001000005

93. Levav, I, Al-Krenawi, A, Ifrah, A, Geraisy, N, Grinshpoon, A, Khwaled, R, et al. Common Mental Disorders Among Arab-Israelis: Findings from the Israel National Health Survey. Isr J Psychiatry Relat Sci (2007). 44:104-13.

94. McCrea, RL, Berger, YG, and King, MB. Body Mass index and Common Mental Disorders: Exploring the Shape of the Association and its Moderation by Age, Gender and Education. Int J Obes (2012). 36:414-21. doi:10.1038/ ijo. 2011.65

95. Oleski, J, Cox, BJ, Clara, I, and Hills, A. Pathological Gambling and the Structure of Common Mental Disorders. J Nerv Ment Dis (2011). 199(12): 956-60. doi:10.1097/NMD.0b013e3182392931

96. King, M, Nazareth, I, Levy, G, Walker, C, Morris, R, Weich, S, et al. Prevalence of Common Mental Disorders in General Practice Attendees across Europe. Br J Psychiatry (2008). 192:362-7. doi:10.1192/ bjp.bp.107.039966

97. Fahey, N, Soni, A, Allison, J, Vankar, J, Prabhakaran, A, Moore Simas, TA, et al. Education Mitigates the Relationship of Stress and Mental Disorders Among Rural Indian Women. Ann Glob Health (2016). 82:779-87. doi:10.1016/j.aogh.2016.04.001

98. Lahelma, E, Laaksonen, M, Martikainen, P, Rahkonen, O, and SarlioLähteenkorva, S. Multiple Measures of Socioeconomic Circumstances and Common Mental Disorders. Soc Sci Med (2006). 63:1383-99. doi:10.1016/ j.socscimed.2006.03.027

99. Said, D, Kypri, K, and Bowman, J. Risk Factors for Mental Disorder Among university Students in Australia: Findings from a Web-Based Cross-Sectional Survey. Soc Psychiatry Psychiatr Epidemiol (2013). 48:935-44. doi:10.1007/ s00127-012-0574-x

100. Haghighatdoost, F, Feizi, A, Esmaillzadeh, A, Feinle-Bisset, C, Keshteli, AH, Afshar, $\mathrm{H}$, et al. Association between the Dietary Inflammatory index and Common Mental Health Disorders Profile Scores. Clin Nutr (2019). 38: 1643-50. doi:10.1016/j.clnu.2018.08.016

101. Thom, R. Common Mental Disorders in People Living with HIV/AIDS. South Afr J HIV Med (2009). 10:8. doi:10.4102/sajhivmed.v10i3.277

102. Bhui, K, Bhugra, D, and Goldberg, D. Causal Explanations of Distress and General Practitioners' Assessments of Common Mental Disorder Among Punjabi and English Attendees. Soc Psychiatry Psychiatr Epidemiol (2002). 37(1):38-45. doi:10.1007/s127-002-8212-9

103. Myer, L, Stein, DJ, Grimsrud, AT, Herman, A, Seedat, S, Moomal, H, et al. DSM-IV-defined Common Mental Disorders: Association with HIV Testing, HIV-Related Fears, Perceived Risk and Preventive Behaviours Among South African Adults. S Afr Med J (2009). 99(5 Pt 2):396-402.

104. Augusto, VG, Perina, KCB, Penha, DSG, Santos, DCA, and Oliveira, VAS. Temporomandibular Dysfunction, Stress and Common Mental Disorder in university Students. Acta Ortop Bras (2016). 24:330-3. doi:10.1590/1413785220162406162873

105. Santos, JAT, Perruci, LG, Pegoraro, NPJ, Scherer, ZAP, Souza, J, Santos, MA, et al. Use of Psychoactive Substances in Women in Outpatient Treatment. Rev Bras Enferm (2019). 72:178-83. doi:10.1590/0034-7167-2018-0399 
106. Jacka, FN, Mykletun, A, Berk, M, Bjelland, I, and Tell, GS. The Association between Habitual Diet Quality and the Common Mental Disorders in Community-Dwelling Adults. Psychosom Med (2011). 73:483-90. doi:10.1097/PSY.0b013e318222831a

107. Nielsen, MBD, Madsen, IEH, Bültmann, U, Christensen, U, Diderichsen, F, and Rugulies, R. Encounters between Workers Sick-Listed with Common Mental Disorders and Return-To-Work Stakeholders. Does Workers' Gender Matter? Scand J Public Health (2013). 41:191-7. doi:10.1177/1403494812470750

108. Tesfaye, M, Hanlon, C, Tessema, F, Prince, M, and Alem, A. Common Mental Disorder Symptoms Among Patients with Malaria Attending Primary Care in Ethiopia: a Cross-Sectional Survey. PLoS One (2014). 9:e108923. doi:10.1371/ journal.pone.0108923

109. Patel, V, Araya, R, de Lima, M, Ludermir, A, and Todd, C. Women, Poverty and Common Mental Disorders in Four Restructuring Societies. Soc Sci Med (1999). 49:1461-71. doi:10.1016/s0277-9536(99)00208-7

110. Moraes, CL, Marques, ES, Reichenheim, ME, Ferreira, MF, and Salles-Costa, R. Intimate Partner Violence, Common Mental Disorders and Household
Food Insecurity: an Analysis Using Path Analysis. Public Health Nutr (2016). 19:2965-74. doi:10.1017/S1368980016001178

111. Meng, X, and D'Arcy, C. Re: A New Discussion for “The Projected Effect of Increasing Physical Activity on Reducing the Prevalence of Common Mental Disorders Among Canadian Men and Women: A National Population-Based Community Study". Prev Med (2013). 56:420-1. doi:10.1016/ j.ypmed.2013.03.009

112. De Silva, MJ, Huttly, SR, Harpham, T, and Kenward, MG. Social Capital and Mental Health: a Comparative Analysis of Four Low Income Countries. Soc Sci Med (2007). 64:5-20. doi:10.1016/j.socscimed.2006.08.044

Copyright (C) 2021 Bezerra, Alves, Nunes and Barbosa. This is an open-access article distributed under the terms of the Creative Commons Attribution License (CC BY). The use, distribution or reproduction in other forums is permitted, provided the original author(s) and the copyright owner(s) are credited and that the original publication in this journal is cited, in accordance with accepted academic practice. No use, distribution or reproduction is permitted which does not comply with these terms. 